\title{
HUBUNGAN PENGGUNAAN KONTRASEPSI PROGESTIN (PIL) PADA IBU MENYUSUI DENGAN KECUKUPAN PRODUKSI ASI DI WILAYAH KERJA PUSKESMAS INDRAPURI ACEH BESAR
}

\author{
Relationship Of The Use Of Progestin (Pil) Contraception In Breastfeeding Mother \\ With Adequacy Of Assembly Production In The Working Area Of The Aceh Besar \\ Indrapuri Health Center \\ Asmaul Husna*1, Nuzulul Rahmi*2 \\ ${ }^{* 1,2}$ Universitas Ubudiyah Indonesia, Jl. Alue Naga Desa Tibang, 23115, Banda Aceh, Aceh \\ *Koresponden asmaulhusna@uui.ac.id
}

\begin{abstract}
Abstrak
Proses pemberian ASI dilakukan melalui kegiatan laktasi. Proses laktasi merupakan proses produksi dan sekresi ASI. Secara fisiologis, laktasi bergantung pada 4 proses, yaitu proses pengembangan jaringan penghasil ASI dalam payudara, proses yang memicu produksi ASI setelah melahirkan, proses untuk mempertahankan produksi ASI dan proses sekresi ASI. Proses-proses ini berlangsung dari masa kehamilan hingga melahirkan dan akhirnya menyusui (WHO, 2018). Untuk mengetahui hubungan penggunaan kontrasepsi progestin pada ibu menyusui dengan kecukupan Asi. Penelitian ini dilakukan di wilayah kerja Puskesmas indrapuri aceh besar pada tanggal 8-13 Juni 2020. Populasi dari penelitian ini adalah seluruh ibu yang mempunyai ibu menyusui di wilayah kerja Puskesmas Indrapuri Aceh Besar berjumlah 125. Jadi jumlah total sampel penelitian ini adalah 48 ibu menyusui dengan kontrasepsi progestrin dan 48 ibu menyusui yang tidak menggunakan kontrasepsi progestrin. Hasil analisis bivariat di dapat bahwa Berdasarkan hasil penelitian yang telah dilakukan maka penelitian dapat mengumpulkan hasil dari penenelitian sebagai berikut terdapat tidak ada hubungan yang bermakna kecukupan ASI dengan penggunaan kontrasepsi progestin (Pil) di Wilayah Kerja Puskesmas Indrapuri Kabupaten Aceh Besar (p>0,05) dan ibu yang menggunakan kontrasepsi progestin 0,5 kali berpeluang tidak cukup ASI dibandingkan dengan ibu yang tidak menggunakan kontrasepsi progestin dengan Hasil Uji chi square test diperoleh nilai $\mathrm{p}$ value 0,403 dengan nilai OR sebesar 0,533.
\end{abstract}


Journal of Healthcare Technology and Medicine Vol. 6 No. 2 Oktober 2020

Universitas Ubudiyah Indonesia

e-ISSN : 2615-109X

\title{
Kata kunci : Penggunaan Kontrasepsi Progestin (Pil)
}

\begin{abstract}
The process of breastfeeding is carried out through lactation activities. Lactation is a process of milk production and secretion. Physiologically, lactation depends on 4 processes, namely the process of developing milk-producing tissue in the breast, the process that triggers the production of breast milk after delivery, the process for maintaining milk production and the process of milk secretion. These processes take place from pregnancy to delivery and finally breastfeeding (WHO, 2018). To determine the relationship between progestin contraceptive use in breastfeeding mothers with breastfeeding adequacy. This research was conducted in the working area of the Indrapuri Aceh Besar Public Health Center on June 8-13 2020. The population of this study were all mothers who had breastfeeding mothers in the working area of the Indrapuri Aceh Besar Community Health Center. So the total sample of this study was 48 breastfeeding mothers with progestrine contraceptives and 48 breastfeeding mothers who did not use progestrin contraceptives. The results of the bivariate analysis show that based on the results of the research that has been done, the research can collect the results of the research as follows, there is no significant relationship between the adequacy of breast milk and the use of progestin contraceptives (Pil) in the working area of Indrapuri Public Health Center, Aceh Besar District ( $p>0.05$ ) and mothers who use progestin contraceptives are 0.5 times more likely to have insufficient breast milk compared to mothers who do not use progestin contraceptives. The results of the chi square test showed a p value of 0.403 with an OR value of 0.533 .
\end{abstract}

\section{Keywords: Progestin Contraceptive Use (Pill)}

\section{PENDAHULUAN}

ASI (Air Susu Ibu) merupakan cairan kehidupan terbaik yang sangat dibutuhkan oleh bayi.ASI mengandung berbagai zat yang penting untuk tumbuh kembang bayi dan sesuai dengan kebutuhannya. Meski demikian, tidak semua ibu mau menyusui bayinya karena berbagai alasan, sebagai contoh: takut gemuk, sibuk, payudara kendor, dan sebagainya, di sisi lain ada juga ibu yang ingin menyusui bayinya tetapi mengalami kendala. Kendala lain yang dihadapi ibu biasanya adalah ASI tidak mau keluar atau produksinya kurang lancar (Safitri, 2016). 
Proses pemberian ASI dilakukan melalui kegiatan laktasi. Proses laktasi merupakan proses produksi dan sekresi ASI. Secara fisiologis, laktasi bergantung pada 4 proses, yaitu proses pengembangan jaringan penghasil ASI dalam payudara, proses yang memicu produksi ASI setelah melahirkan, proses untuk mempertahankan produksi ASI dan proses sekresi ASI. Proses-proses ini berlangsung dari masa kehamilan hingga melahirkan dan akhirnya menyusui (WHO, 2018).

Kehidupan sehari-hari kita sering menemukan ibu-ibu yang tidak berhasil dalam menyusui bayinya atau bahkan menghentikan menyusui bayinya lebih dini dengan berbagai alasan. Beberapa hasil penelitian menunjukkan bahwa 98 ribu dari 100 ribu ibuibu yang mengatakan produksi ASI-nya kurang, padahal sebenarnya mereka mempunyai cukup ASI, tetapi kurang mendapat informasi tentang manajemen laktasi yang benar, posisi menyusui yang tepat, serta terpengaruh mitos-mitos tentang menyusui, yang umumnya dapat menghambat produksi ASI. Bayi yang kurang mendapatkan ASI atau kurang minum, pada umumnya bukan karena ibunya yang tidak mau memproduksi ASI sebanyak yang diperlukan oleh bayi, tetapi disebabkan oleh beberapa faktor (Hetty, 2016).

Menurut WHO (2019) dari 136,7 juta bayi lahir diseluruh dunia dan hanya 32,6\% dari mereka yang disusui secara eksklusif selama 6 bulan pertama. Berdasarkan Data Profil Kesehatan tahun 2019, jumlah bayi yang mendapatkan ASI eksklusif sampai 6 bulan sebanyaj 29,5\% dan bayi yang mendapatkan ASI eksklusif 0-5 bulan sebanyak 54\% (Kemenkes RI, 2019). Data profil kesehatan Provinsi Aceh tahun 2019, menyatakan bahwa presentasi bayi yang diberikan ASI eksklusif terjadi peningkatan pada tahun 2017 sebanyak 48\%, tahun 2018 sebanyak 55\% dan sedikit menurun pada tahun 2019 sebanyak $53 \%$.

Beberapa faktor yang dapat mempengaruhi produksi ASI antara lain frekuensi penyusuan, berat lahir, umur kehamilan saat melahirkan, umur dan paritas, stress dan penyakit akut, konsumsi rokok, konsumsi alkohol, makanan ibu, dukungan suami dan keluarga lain, perawatan payudara, jenis persalinan, rawat gabung dan kontrasepsi (Haryono R, 2014).

Kontrasepsi hormonal terutama kontrasepsi suntikan merupakan kontrasepsi yang paling diminati akseptor KB yang paling aman, praktis, tidak perlu mengingat-ingat setiap hari. Kontrasepsi suntikan yang dapat diberikan kepada ibu menyusui adalah suntikan 
yang berbasis progestin (BKKBN, 2013). Kontrasepsi suntikan ini dapat diberikan pada ibu menyusui segera setelah masa pasca persalinan. Fungsi hormon Progestin adalah mempengaruhi pertumbuhan dan ukuran alveoli (Hariyanti, 2017).

Pemberian progestin (DMPA) berdampak pada produksi ASI jika diberikan pada awal post partum. Sedangkan hormon esterogen yang dapat menurunkan jumlah produksi ASI. ASI merupakan sumber nutrisi terbaik bagi bayi, karena sifatnya alami dan komposisi lengkap serta sesuai bagi bayi. ASI sangat penting bagi bayi karena ASI makanan utama bagi bayi. ASI dikatakan cukup bagi bayi jika terdapat ciri-ciri antara antara lain ASI merembes keluar puting susu ibu, bayi menyusui selama (>10 menit) setiap kali menyusu, setelah menyusui bayi tidak rewel dan bayi buang air kecil sering (> 6 kali) dalam sehari, ibu mendengar suara menelan ketika bayi menelan ASI, ibu merasa geli setiap kali bayi menyusu, anak menyusui lebih dari enam kali dalam sehari, bayi buang air besar lebih dari tiga kali dalam sehari (Astutik, 2017).

Penelitian yang dilakukan oleh tati dkk, bahwa ASI berkriteria lancar yaitu sebanyak 77 orang $(96,3 \%)$. Begitu juga dengan akseptor KB suntik kombinasi juga sebagian besar produksi ASI berkriteria lancar yaitu yaitu sebanyak 76 orang (95\%). Analisa data dengan Mann Whitney didapatkan hasil $\mathrm{p}$ sebesar 0,70 yang berarti bahwa $\mathrm{p}>0,05(0,70>0,05)$ dengan demikian Ho ditolak berarti tidak ada perbedaan produksi ASI pada akseptor KB suntik kombinasi dan progestin (Tanti Budhi Hariyanti, 2017).

Pada masa menyusui (laktasi) hormon prolaktin dan oksitosin meningkat. Hormon prolaktin berfungsi memproduksi ASI sehingga mengisi alveoli sedangkan hormon oksitosin bekerja memeras ASI dari alveoli sehingga ASI disekresi. Dalam keadaan fisiologis setelah menstruasi hari ke- 5 hormon FSH akan meningkat sehingga folikel matang. Namun pada masa laktasi, tingginya hormon prolaktin dan oksitosin akan memberikan umpan balik negatif terhadap hormon FSH (Follicle Stimulating Hormone) dan LH (Luteinizing Hormone) sehingga proses pematangan sel telur tidak terjadi. Apabila pada masa laktasi ibu menggunakan kontrasepsi hormonal, maka hormon laktasi yaitu hormon prolaktin dan oksitosin akan ditekan sehingga proses pematangan sel telur segera terjadi, ibu segera masuk pada masa subur dan produksi ASI terganggu (Jannah A, 2014).

Berdasarkan hasil Riskesdas 2018 menyebutkan bahwa proporsi penggunaan alat kontrasepsi setelah persalinan pada perempuan di Indonesia adalah sebagai berikut : 
Journal of Healthcare Technology and Medicine Vol. 6 No. 2 Oktober 2020

Universitas Ubudiyah Indonesia

e-ISSN : 2615-109X

Sterilisasi pria $(0.2 \%)$ Kondom Pria (1.1\%) sterilisasi wanita (3.1\%) Susuk KB (4.7\%) Suntikan 1 bln (6.1\% ) IUD/ IKDR/ Spiral (6.6\%) Pil (8,5\%) Suntikan 3 bln (42,4\%) Tidak menggunakan (27,1\%). Sementara itu di Provinsi Aceh pada tahun 2018 jumlah akseptor adalah sebagai berikut : 4.075 IUD, 16 MOP, 2.146 MOW, 4.71 implant, 49.789 suntikan, 33.508 Pil, dan 6.864 kondom. Di Kabupaten Aceh Besar diketahui bahwa jumlah akseptor IUD adalah 374, MOP tidak ada, MOW 64 orang. Implant 304 orang, suntikan 2.362 orang, pil nya 1.481 orang dan kondom 218 orang.

\section{METODE PENELITIAN}

Penelitian ini merupakan penelitian analitik dengan desain case control, yaitu studi analitik yang menganalisis hubungan kausal dengan menggunakan logika terbalik, yaitu menentukan penyakit (outcome) terlebih dahulu kemudian mengidentifikasi penyebab (faktor risiko). Penelitian ini dilakukan di wilayah kerja Puskesmas indrapuri aceh besar pada tanggal 8-13 Juni 2020. Populasi dari penelitian ini adalah seluruh ibu yang mempunyai ibu menyusui di wilayah kerja Puskesmas Indrapuri Aceh Besar berjumlah 125. Jadi jumlah total sampel penelitian ini adalah 48 ibu menyusui dengan kontrasepsi progestrin dan 48 ibu menyusui yang tidak menggunakan kontrasepsi progestrin.

\section{ANALISIS DATA}

Analisis univariat bertujuan untuk menjelaskan atau mendeskripsikan karakteristik setiap variabel penelitian. Pada analisis univariat peneliti hanya melihat distribusi frekuensi dan persentase setiap variabel yang diteliti yaitu pengetahuan, dukungan suami, budaya dengan pemberian ASI eksklusif. Analisis bivariat pada penelitian ini menggunakan uji statistik chi square, dengan batas kemaknaan $(\alpha=0,05)$ atau Confident Level $(\mathrm{CL})=95 \%$.

\section{HASIL PENELITIAN}

\section{Tabel 1}

Hubungan Penggunaan kontrasepsi Progestin (Pil) dengan Kecukupan ASI Di Wilayah Kerja Puskesmas Indrapuri Kabupaten Aceh Besar tahun 2020 


\section{Penggunaan Kontrasepsi}

Progestin

\begin{tabular}{|c|c|c|c|c|c|c|c|c|c|}
\hline \multirow{3}{*}{ No. } & \multirow{3}{*}{$\begin{array}{c}\text { Kecukupan } \\
\text { ASI }\end{array}$} & \multicolumn{4}{|c|}{ 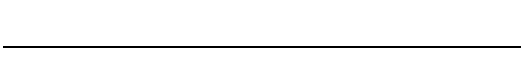 } & & & \multirow{3}{*}{$\begin{array}{c}p \\
\text { value }\end{array}$} & \multirow{3}{*}{$\begin{array}{c}\text { OR } \\
(95 \% \mathrm{CI})\end{array}$} \\
\hline & & \multicolumn{2}{|c|}{ Menggunakan } & \multicolumn{2}{|c|}{ Tidak } & \multirow{2}{*}{$\mathbf{n}$} & \multirow{2}{*}{$\%$} & & \\
\hline & & $\mathbf{n}$ & $\%$ & $\mathbf{n}$ & $\%$ & & & & \\
\hline 1. & Cukup & 22 & 55,0 & 18 & 45,0 & 40 & 100 & & 0,533 \\
\hline 2. & Tidak & 26 & 46,4 & 30 & 53,5 & 56 & 100 & 0,403 & $\begin{array}{c}(0,176- \\
1,619)\end{array}$ \\
\hline & Total & 48 & 50,0 & 48 & 50,0 & 96 & 100 & & \\
\hline
\end{tabular}

Berdasarkan tabel di atas dapat dijelaskan menunjukkan bahwa dari 48 responden pada kelompok kasus terdapat 55,0\% yang cukup produksi ASI nya dan dari 48 responden pada kelompok kontrol terdapat 53,6\% responden yang tidak cukup produksi ASI nya. Hasil Uji chi square test diperoleh nilai $\mathrm{p}$ value 0,403 dengan nilai $\mathrm{OR}$ sebesar 0,533 sehingga dapat disimpulkan bahwa terdapat tidak ada hubungan yang bermakna kecukupan ASI dengan penggunaan kontrasepsi progestin (Pil) di Wilayah Kerja Puskesmas Indrapuri Kabupaten Aceh Besar ( $p>0,05)$ dan ibu yang menggunakan kontrasepsi progestin 0,5 kali berpeluang tidak cukup ASI dibandingkan dengan ibu yang tidak menggunakan kontrasepsi progestin.

\section{PEMBAHASAN}

\section{Hubungan Penggunaan kontrasepsi progestin (Pil) dengan kecukupan ASI di Wilayah} Kerja Puskesmas Indrapuri Aceh Besar.

Hasil penelitian menunjukkan bahwa dari 48 responden pada kelompok kasus terdapat 55,0\% yang cukup produksi ASI nya dan dari 48 responden pada kelompok kontrol terdapat 53,6\% responden yang tidak cukup produksi ASI nya. Hasil Uji chi square test 
Journal of Healthcare Technology and Medicine Vol. 6 No. 2 Oktober 2020

Universitas Ubudiyah Indonesia

e-ISSN : 2615-109X

diperoleh nilai $\mathrm{p}$ value 0,403 dengan nilai OR sebesar 0,533 sehingga dapat disimpulkan bahwa terdapat tidak ada hubungan yang bermakna antara kecukupan ASI dengan penggunaan kontrasepsi progestin di Wilayah Kerja Puskesmas Indrapuri Kabupaten Aceh Besar $(p>0,05)$ dan ibu yang menggunakan kontrasepsi progestin 0,5 kali berpeluang tidak cukup ASI dibandingkan dengan ibu yang tidak menggunakan kontrasepsi progestin.

Hasil penelitian ini sejalan dengan penelitian yang dilakukan oleh Yuliasari.D (2015) tentang hubungan penggunaan KB pil kombinasi dengan produksi asi pada ibu menyusui Di Puskesmas Bernung Kabupaten Pesawaran tahun 2015 yang menunjukkan bahwa sebagian besar responden tidak menggunakan KB Pil yaitu sebanyak 35 responden (36,5\%). Sebagian besar responden dengan produksi ASI yang cukup yaitu sebanyak 57 responden $(59,4 \%)$. Ada hubungan penggunaan KB Pil dengan produksi ASI pada ibu menyusui di Wilayah Kerja Puskesmas Bernung Kabupaten Pesawaran Tahun 2014 ( $p$ value $0,223)$.

Hasil penelitian ini tidak sejalan dengan penelitian yang dilakukan Safitri I (2016) yang menyatakan bahwa ada pengaruh antara penggunaan alat kontrasepsi terhadap kelancaran produksi ASI di Desa Bendan, Kecamatan Banyudono, Kabupaten Boyolali (nilai $\mathrm{p}=0,022<0,05$ ). Dalam penelitiannya Safitri I menemukan penggunaan kontrasepsi kombinasi hormon estrogen dan progesteron berkaitan dengan penurunan volume dan durasi ASI, sebaliknya bila kontrasepsi hanya mengandung progesteron maka tidak ada dampak terhadap volume ASI.

Hasil penelitian ini juga tidak sejalan dengan penelitian yang dilakukan La Ode Alifariki, dkk (2019) menunjukkan bahwa sebagian besar menggunakan 3 jenis kontrasepsi hormonal suntik 3 bulan (46,3\%), mengikutijenispil mini sebanyak 9 orang (22,0\%), implant sebanyak 6 orang (14,6\%), suntik 1 bulan sebanyak 5 orang $(12,2 \%)$ dan paling sedikitmenggunakanpilkombinasi 2 orang (4,9\%). Produksi ASI adalah 27 orang $(65,9 \%)$ dankategorisaatiniadalah 14 orang $(34,1 \%)$. Hasil uji statistic menunjukkan bahwa ada hubungan antara penggunaan kontrasepsi hormonal dan produksi ASI di area kerja Puskesmas Poasia, Kota Kendari pada tahun 2019, dengan nilai p 0,004 <0,05. 
Pada masa menyusui (laktasi) hormon prolaktin dan oksitosin meningkat. Hormon prolaktin berfungsi memproduksi ASI sehingga mengisi alveoli sedangkan hormon oksitosin bekerja memeras ASI dari alveoli sehingga ASI disekresi. Dalam keadaan fisiologis setelah menstruasi hari ke- 5 hormon FSH akan meningkat sehingga folikel matang. Namun pada masa laktasi, tingginya hormon prolaktin dan oksitosin akan memberikan umpan balik negatif terhadap hormon FSH (Follicle Stimulating Hormone) dan LH (Luteinizing Hormone) sehingga proses pematangan sel telur tidak terjadi. Apabila pada masa laktasi ibu menggunakan kontrasepsi hormonal, maka hormon laktasi yaitu hormon prolaktin dan oksitosin akan ditekan sehingga proses pematangan sel telur segera terjadi, ibu segera masuk pada masa subur dan produksi ASI terganggu (Jannah A, 2014).

Berbeda dengan pil kombinasi estrogen dan progesteron, pil KB yang hanya berisi progestin memang ditujukan untuk ibu yang masih menyusui. Beberapa organisasi kesehatan, seperti Badan Kesehatan Dunia (WHO), American Academy of Pediatrics, dan American College of Obstetricians and Gynecologists, telah menyepakati bahwa pil KB progestin cocok digunakan ibu menyusui. Pil KB progestin tidak memengaruhi produksi ASI. Bahkan pada sebagian ibu menyusui, terjadi sedikit kenaikan jumlah ASI yang dihasilkan ketika menggunakan pil KB. Memang, progestin kemungkinan akan tetap masuk ke dalam ASI, tapi jumlahnya sangat kecil. Banyak penelitian hingga saat ini juga tidak menemukan bukti bahwa keberadaan sedikit progestin dalam ASI akan berdampak pada perkembangan bayi.

ASI (Air Susu Ibu) merupakan cairan putih yang dihasilkan oleh kelenjar payudara wanita melalui proses laktasi. ASI terdiri dari berbagai komponen gizi dan non gizi. Komposisi ASI tidak sama selama periode menyusui, pada akhir menyusui kadar lemak 45 kali dan kadar protein 1,5 kali lebih tinggi daripada awal menyusui. Juga terjadi variasi dari hari ke hari selama periode laktasi. Keberhasilan laktasi dipengaruhi oleh kondisi sebelum dan saat kehamilan. Kondisi sebelum kehamilan ditentukan oleh perkembangan payudara saat lahir dan saat pubertas. Pada saat kehamilan yaitu trimester II payudara mengalami pembesaran karena pertumbuhan dan difrensiasi dari lobuloalveolar dan sel epitel payudara. Pada saat pembesaran payudara ini hormon prolaktin dan laktogen placenta aktif bekerja yang berperan dalam produksi ASI (Suharyono, 2008). 
Journal of Healthcare Technology and Medicine Vol. 6 No. 2 Oktober 2020

Universitas Ubudiyah Indonesia

e-ISSN : 2615-109X

Peneliti berasumsi bahwa tidak ada tidak ada hubungan yang singnifikan antara kecukupan ASI dengan penggunaan kontrasepsi progestin (Pil) dikarenakan ada faktor lain yang memang membuat Asi tidak cukup untuk bayi, salah satu faktornya adalah seperti kekurangan asupan gizi ibu selama menyusui bayinya. Oleh karena itu dengan nutrisi yang kurang juga akan memepengaruhi Asi yang tidak memcukupi bagi si bayi. Dan juga pada kandungan pil kombinasi adalah gabungan antara hormone estrogen yang sifatnya menghambat produksi ASI dan sebaliknya progesterone melancarkan produksi ASI. Oelh karena itu kontrasepsi progestin (pil) tidak akan mempengaruhi Asi bagi ibu selama menyusui bayi. Dan juga didukung oleh pengetahuan ibu yang sudah mengerti cara memilih alat kontrasepsi yang benar selama menyusui bayinya.

\section{KESIMPULAN DAN SARAN}

\section{Kesimpulan}

Berdasarkan hasil penelitian yang telah dilakukan maka penelitian dapat mengumpulkan hasil dari penenelitian sebagai berikut terdapat tidak ada hubungan yang bermakna kecukupan ASI dengan penggunaan kontrasepsi progestin (Pil) di Wilayah Kerja Puskesmas Indrapuri Kabupaten Aceh Besar $(p>0,05)$ dan ibu yang menggunakan kontrasepsi progestin 0,5 kali berpeluang tidak cukup ASI dibandingkan dengan ibu yang tidak menggunakan kontrasepsi progestin dengan Hasil Uji chi square test diperoleh nilai p value 0,403 dengan nilai OR sebesar 0,533.

\section{Saran}

Diharapkan kepada ibu menyusui agar terus dapat meningkatkan wawasan dan pengetahuan tentang penggunaan KB progestin dengan Kecukupan ASI dan juga diharapakan dapat terus memantau dan memonitoring penggunaan kontrasepsi pada ibu menyusui

\section{REFERENSI}

Astutik, R. (2017). Payudara dan Laktasi. Jakarta: Salemba Medika. 
Journal of Healthcare Technology and Medicine Vol. 6 No. 2 Oktober 2020

Universitas Ubudiyah Indonesia

e-ISSN : 2615-109X

BKKBN. (2013). Pemantauan Pasangan Usia Subur Melalui Mini Survei Indonesia. Jakarta: BKKBN.

Hariyanti. (2017). Perbedaan Produksi ASI pada Akseptor KB Suntik Kombinasi dan Progestin di BPS Anugerah Kabupaten Malang. Skripsi.

Haryono R, S. S. (2014). Manfaat ASI Eksklusif Untuk Buah Hati Anda. Yogyakarta: Gosyen Publising.

Hetty. (2016). Inisiasi Menyusui Dini (IMD) Terhadap Kelancaran ASI Pada Ibu Menyusui Usia 0-1 Bulan Di Wilayah Kerja Puskesmas Kutorejo Kabupaten Mojokerto. Medika Majapahit.; 8(1), 26-39.

Jannah A. (2014). Gambaran Tingkat Pengetahuan Ibu Nifas tentang Kontrasepsi Metode Amenore Laktasi (MAL) [Internet]. vailable from: http://digilib.stikeskusumahusada.ac.id/files/disk1/12/01-gdl-yuniseniwa594-1-b11059y-i.pdf

La Ode Alifariki, dkk. (2019). Penggunaan Kontrasepsi Hormonal dan Produksi Air Susu Ibu di Puskesmas Poasia. Jurnal Penelitian Kesehatan Suara Forikes. Volume 11 Nomor 1, Januari 2020

Safitri. (2016). Faktor-Faktor Yang Mempengaruhi Kelancaran Produksi ASIPada Ibu Menyusui di Desa Bendan, Kecamatan Banyudono, Kabupaten Boyolali. Surakarta: Universitas Muhammadiyah Surakarta, 1-14.

Safitri I.( 2016). Pengaruh penggunaan alat kontrasepsi terhadap kelancaran produksi ASI di Desa Bendan, Kecamatan Banyudono, Kabupaten Boyolali.

Suharyono, G.J. Ebrahim. (2008). Air Susu Ibu. Jogjakarta: Gajah Mada University Press.

Tanti Budhi Hariyanti, A. S. (2017). Perbedaan Produksi Asi Pada Akseptor Kb Suntik Kombinasi Dan Progestin. Journal of Nursing Care \& Biomolecular - Vol 2 No 1, 36-41

WHO, U. (2018). Breastfeeding within an hour after birth is critical for saving newborn lives. In: New Releases about 3 in 5 babies not breastfed in the first hour of life. New York: World Health Organization (WHO).

Yulia sari,Dewi. (2015). Hubungan Penggunaan KB Pil Kombinasi dengan produksi Asi pada ibu menyusui di puskesmas bernung kabupataen sawaran tahun 2014. Holistik Jurnal Kesehatan. Vol 9, No.4. 